Copyright ( ) 2016 SCAD Independent

All Rights Reserved

Printed in the Indonesia
Jurnal Ilmiah Peuradeun Vol. 4, No. 3, Sep 2016

\title{
SOCIAL IMPACT OF MANGROVE LAND CONVERSION IN DIMENSIONS AS RURAL SUSTAINABILITY
}

(Case Study: Tapak Kuda Village, District of Tanjung Pura, Langkat, North Sumatra Province)

\author{
1A Hadian Pratama; ${ }^{2 B u d i}$ Gunawan; ${ }^{3}$ Budi Cahya \\ ${ }^{1}$ Politeknik Piksi Ganesha Bandung \\ 2-3Program Study of Magister Environmental Science, Padjadjaran University, Bandung \\ Email: didihardian@yahoo.com
}

Received: May 11, 2016

Accepted: Aug 13, 2016

Published: Sep 28, 2016

Article Url: https:/ /journal.scadindependent.org/index.php/jipeuradeun/article/view/109

\begin{abstract}
Mangrove ecosystem is an important part of the coastal environment. One of the problems in almost all coastal areas in Indonesia is the degradation of mangrove area. In the coastal areas of Langkat Regency, precisely in the Tapak Kuda Village is also facing the same thing. In the last 15 years, mangrove area has reduced quite high. One of them is caused by the conversion of mangrove land into ponds. The existence of mangrove ecosystems is related to socio-economic life of society that causes the decline of mangrove area and the changing environmental conditions of social life. The results showed that the conversion of mangrove land brought the social impact on residents' lives. Changes in the types of jobs are fishermen decreased $24 \%$, the percentage of farmers rose $19 \%$ and fish farmers also rose $10 \%$. Incomerelated conditions, $24 \%$ of people feel steady and have sufficient income to meet the families' needs, $43 \%$ of people feel sometimes high income is not enough to meet families' needs and 33\% of people feel low income that make the families' needs are not fulfilled. The condition of public education level has increased, the percentage of people completing primary school rose $7 \%$, junior high was up $21 \%$, and high school $16 \%$. Regarding the use of natural resources, there were only $35 \%$ of the natural resources that could be managed by the community. Community land use patterns are 10\% of ponds, $30 \%$ of fields, $20 \%$ of fishing areas and $40 \%$ of conservation areas.
\end{abstract}

Keywords: Mangrove, Land Conversion, Social Life Changes 


\section{A. Introduction}

The mangrove ecosystem is an important part of the coastal environment. Mangrove ecosystem has a wide range of ecosystem services in the backbone of subsistence at once human activity. One of ecosystem, services in the mangrove forest as the provision of services (provisioning service), (Harahap, 2001). Service provision mangrove ecosystem is an advantage that can be obtained either directly or indirectly by humans.

Among other ecosystem services, service provision is easily calculated ecosystem services quality and quantity for direct use by humans. In the mangrove ecosystem, providing services that can be calculated is the utilization of mangrove forests and fauna that live in it or associated with the mangrove ecosystem by utilizing the food and make the mangrove ecosystem as a habitat (Kustiawan, 1997).

Besides existence that has a function for the ecological balance of the environment, the mangrove forest also has a social function for the human economy that is as a source of livelihood and production of various types of timber and non-timber. The economic functions of mangrove forests with regard to the use of products that can be bought and sold, both wood designated as firewood, charcoal fuel, building materials, pulp and tannin and non-timber such as medicine and fish. Utilization of mangrove forests as environmental services, such as; tourist spots and natural laboratory for education (Kusmana, 2003).

The existence of mangrove in Langkat got the pressures of human activities that cause a variety of damage. (Hasbullah, 2007). Some of the factors that led to the decline of mangrove forest area, One of them is the conversion of mangrove forest into a variety of other uses: such as ponds, residential and industrial areas uncontrollably (Dahuri, et al. 1996).

According to data Bappeda North Sumatra (2011) mangrove area in North Sumatra, which has been converted, recorded at $62.50 \%$ Asahan regency, Langkat $74.21 \%$, 48.54\% Labuhan Batu district, Deli Serdang regency $51.23 \%$, 43\% South Tapanuli, Central Tapanuli district, Nias $38.25 \%$ and $37.21 \%$. Irwanmay (2004) states that form the biggest mangrove conversion occurred in the district of Tanjung Pura Langkat 
which amounted to 15753 ha. Transition function of mangrove land in Tanjung Pura Desa Bubun found in 21\%, 56\% Village Tapak Kuda Village, fragile as $23 \%$. Land conversion biggest mangrove located in the village of Tapak Kuda cause environmental damage and should be rehabilitated.

Tapak Kuda village have the characteristics of coastal areas. The village area surrounded by mangrove forests, which reached 62\% (district of Tanjung Pura 2008). The existence of mangrove forests were perceived villagers as forest producers, but the need to increase revenues into the early life of mangrove land clearing activities for aquaculture activities, starting from an area in the Tapak Kuda village for shrimp and fish ponds in the 1990s were years the beginning of the activity over the land for the pond which is then followed by other regions until 2006an.

Economic factors such as income inequality between fish farmers is higher than the traditional fishermen or social conditions as fish farmers more appreciated than the traditional fishermen, the cause of the shift of the fishing profession become farmers. Farmers felt to have a clear working rhythm with stable employment conditions. Permission is granted local governments to open ponds in an effort improve the local economy and local revenue into a number of factors for the activities of the conversion of mangrove land (Irwanmay, 2004).

Tread village Horses have public profiles with characteristics of its own coast. The level of mangrove land conversion that occurred in the village of Tapak Kuda is a region greater than most other villages in the district of Tanjung Pura. Changes livelihoods and incomes of the land conversion of mangroves in the village of Tapak Kuda allow changes in social life between before and after the occurrence of land conversion of mangrove transformation of the land of mangroves due to human activities lead to changes in environmental conditions in the village of Tapak Kuda form of damage to mangrove ecosystems, on the other hand the public has the opportunity to be able to develop the village through the establishment of new activities. However, the level of damage mangrove areas due to land conversion has an impact on the environment and people's lives around in the future. The importance of this research was conducted as an analysis of the environmental changes that have an impact on the social life of the community in the village of Tapak Kuda. 


\section{B. Method}

This study uses a quantitative-qualitative research design, quantitative approach used to calculate the results of the questionnaire and present in the form of percentages and diagram, a qualitative approach was used to analyze the results of the calculation and explain the facts to theory (Cresswell, 2009).

The number of samples in this study amounted to 81 families in the village of Tapak Kuda, langkat North Sumatra. In measuring the social impact on people's lives in a look at the condition of livelihoods, education level, income level, patterns of ownership and use of natural resources and natural resource utilization patterns. Hadi (1995), in analyzing the extent of reduction in the number of mangrove areas, using trend analysis with an average semi technique to test the research hypothesis testing Paired T-test.

\section{Research Finding and Discussion}

Land conversion mangrove in the village of Tapak Kuda impact on the social life of the community, while the social impact over the function land mangrove in the village of Tapak Kuda are:

\section{Conditions of Employment.}

Changes in the state of mangrove forests in the village of Tapak Kuda too affect employment opportunities in the village of Tapak Kuda, impact social employment described as follows:

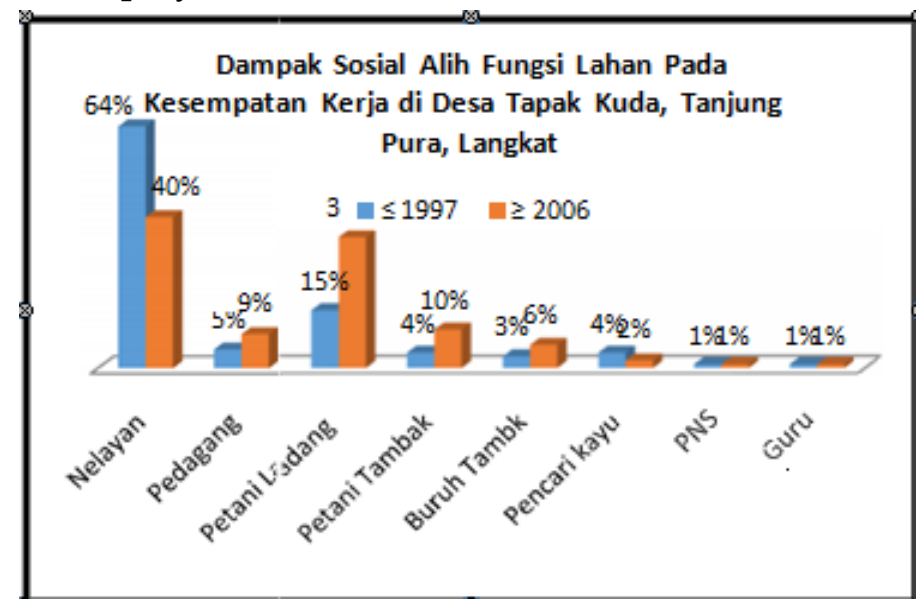


The social impact of mangrove land conversion in the village of Tapak horse looks on employment where fishermen, entrepreneur, farmers fields that the percentage of the number experiencing significant changes, experienced fishermen a decrease of $24 \%$, the percentage of farmers fields rose $19 \%$ and farmers pond percentage also rose $10 \%$.

\section{Income Level condition.}

Changes in environmental conditions directly influence income resulting based on environment, the value of the including money each year has also changed the cost of the shopping needs of families so the numbers rupiah gained between 1997 down to 2006 and above different value of earnings, but the relevant public perceived value family income from daily livelihood described as following:

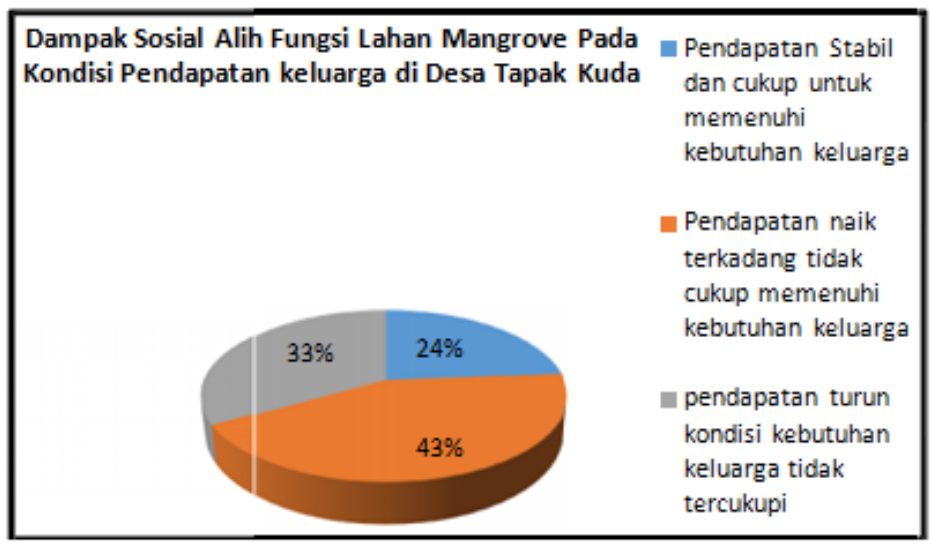

The mangrove ecosystem from damage by an average of Rp. 667562 or $33.89 \%$ of income before any damage. The thing that same occurred also in the village of Tapak Kuda which have a large effect on economic life of the communities involved in the exploitation of resource natural. In the Millennium Ecosystem Assessment (2005) stated that linkages between poverty and environmental degradation confirms the need for reconciliation between conservation and development.

\section{Education Level condition.}

Social Impact of mangrove land conversion brings a change in state level of education in society, people's incomes rise the period on land conversion are $1998-2006$ for activities embank and fishing, this can 
generate a double income to meet family needs, one of which is the cost of education for family members. Here is an overview of the comparison condition of community education in the village Tapak Kuda.

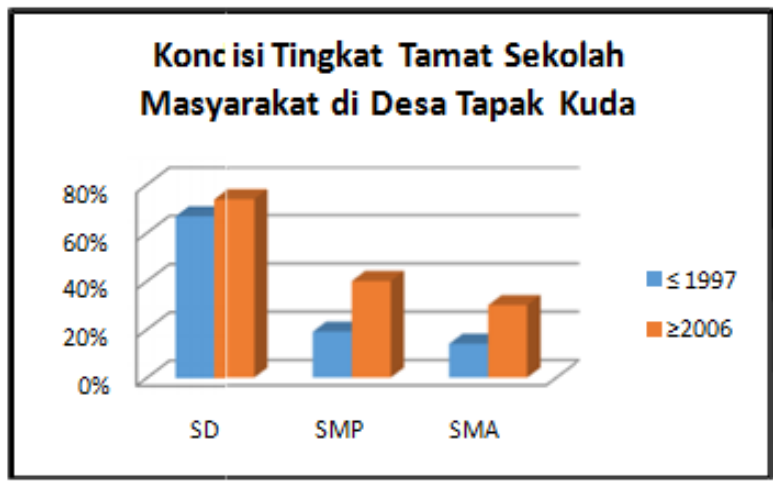

The results of an increase in the percentage of school graduates on the ladder higher in the community in the village of Tapak Kuda. community graduated SD percentage rose $7 \%$, junior high school graduation, $21 \%$, and $16 \%$ graduated from high school. Increased participation school because earnings results.

\section{Patterns of Ownership and Use of Natural Resources.}

After the environmental damage in the village of Tapak Kuda Government Have arranged for restrictions on the use of natural resources in the village Tapak Kuda, it causes conversion regions want ecological function gradually restored. Social impacts of over the function of mangrove land in the village of Tapak Kuda then use the SDA in the following conditions:

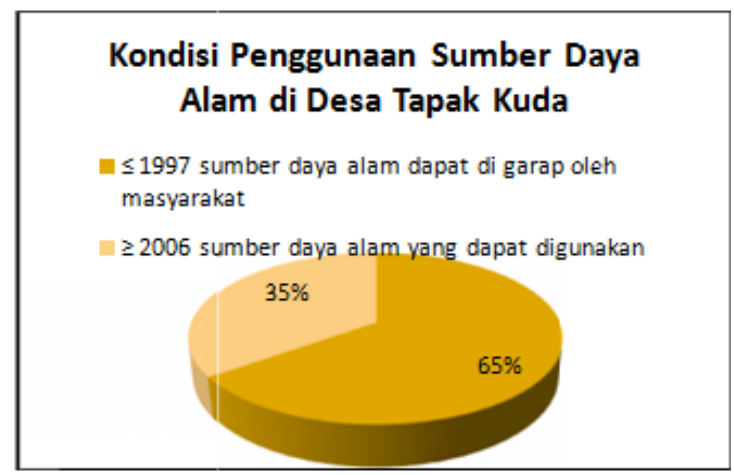


The social impact on the use of natural resources in the form of 35\% the potential of natural resources that can be managed by the community post over function occurs. The usage patterns are regulated by the government village is a manifestation of the government's efforts to carry out rehabilitation the state of natural resources in the form of mangrove forests in the village of Tapak Kuda.

\section{Pettern of Utilization of Natural Resources.}

Natural Resources located in the village of Tapak Kuda forested mangrove, environment waters and vacant land. but in utilization in 1998 2006, more people use mangrove forest for livelihood activities, after conversion mangrove land occurred and society have failed in the land use conditions of use of natural resources by community described as follows:

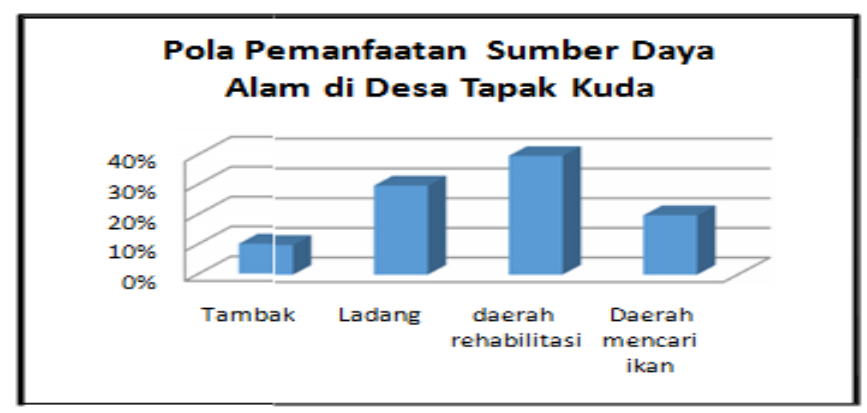

The social impact for the lives of villagers from land conversion Mangrove is a transition in other activities in the cultivation natural resources, the transfer of land use trends seen on field activities, while the activities of the public attempted to turnover economic activity.

Testing the validity of the product moment correlation coefficient Pearson, the validity test in the average yield obtained from each $r$ correlation is 0.49 beyond the number of measurement reliability 0.3 Critical means of measuring instruments that are Cranach Alpha obtained the minimum valid. 0.61 with reliability estimation criteria must be met by a measuring tool is 0.3 , which means that the overall measuring tool already has a reliable internal consistency. 
Hypothesis analysis using Paired Samples T-test. Process included in the calculation (Appendix 6), the results of calculations by formula as follows:

$$
\begin{aligned}
\mathrm{t} & =\frac{696,876}{3952,901 \sqrt{81}} \\
& -\frac{\text { Uy0.010 }}{3952,901.9} \\
& =\frac{696,876}{322.113}=\mathbf{2 , 2 3 1}
\end{aligned}
$$

Value $\mathrm{T}$ is used to prove the hypothesis of the author, by comparing it with the table-t. The benchmark in view Table-t, i.e. taking into account the Degree of Freedom, as follows:

$$
\begin{aligned}
& d f=N-2=81-1=80 \\
& \alpha=0.05
\end{aligned}
$$

The following is a calculation T Table:

$$
\begin{aligned}
\mathrm{T}_{\text {tabel }} & =\mathrm{t}_{0.05 / 2(81-1)} \\
& =\mathbf{1 . 6 4 4}
\end{aligned}
$$

$\mathrm{T}$-table view in the table Based on the value of table-t with $\alpha=0.05$ in two-sided test such as the appendix, it is known that is $81=2,231$. Based on this it can be deduced because $\mathrm{T}_{\text {calculate }}>\mathrm{T}_{\text {table, namely }} 2.231>1.644$, then $\mathrm{Ho}$ is rejected and $\mathrm{Ha}$ accepted. So the hypothesis that there are differences in the social living conditions society before and after the occurrence of mangrove land conversion in Tapak Kuda Village, Village Tanjung Pura, Langkat, North Sumatra acceptable.

\section{Conclusion}

The social impact of land conversion of mangrove resulted in changes in social conditions seen at:

1. Employment opportunities change the type of work in the community where the percentage of the number of fishermen has decreased over the land before and after the $64 \%$ conversion of mangrove land into $40 \%$ decreased by $24 \%$, increase in the number of farmers whose fields occurred either before the conversion of mangroves by $15 \%$ to $34 \%$. 
2. The income level of the people experience changes namely $24 \%$ of the public feel stable and sufficient income to meet the needs of families, $44 \%$ of people feel the revenue up sometimes does not quite meet the needs of families and $33 \%$ of people feel the family needs income down condition is not fulfilled.

3. The level of public education has increased the number of primary school before any land conversion of mangrove $67 \%$ after the conversion of primary school to $74 \%$, graduated from junior high school before land conversion of mangroves by $19 \%$ after the conversion to $40 \%$ and high school graduates also experience increase the percentage of graduate education that before land conversion of $14 \%$ after the conversion of mangrove land widened $30 \%$. It thus in because of income levels rise when the land conversion where embank activities into more income for the family.

4. In the conditions of ownership and use of Natural Resources, which before the conversion occurred in 1997 down to the natural resources in the community working on reaching $65 \%$, whereas in the aftermath of land conversion of mangrove land that can be cultivated by people only $35 \%$. It was enacted as a local government environmental rehabilitation of damaged businesses.

5. In the conditions of use of natural resources by the community to change the function where the use of land for farming, amounted to $30 \%, 20 \%$ area for fish, fishpond $10 \%$ and $40 \%$ conservation area. The high use of land for conservation activities as one of the local government and community efforts to restore the function of the environment and conditions of the pattern of community life.

Mangrove rehabilitation activities in the village of Tapak Kuda are one effort in improving and creating sustainable management of mangrove ecosystems.

\section{Bibliography}

Abdullah, M. (2006). Pengelolaan Hutan Mangrove Berbasis Masyarakat di Kabupaten Langkat. Tesis. Program Pascasarjana. Universitas Sumatera Utara. 
Alfian, M. (2007). Valuasi Ekonomi Konversi Hutan Mangrove Untuk Budidaya Tambak. Tesis. Program Pasca Sarjana. Institut Pertanian Bogor.

Arief, A. (2003). Hutan Mangrove Fungsi dan Manfaatnya. Penerbit Kanisius Yogyakarta.

Arikunto, S. (2006). Prosedur Penelitian. Jakarta: Rineka Cipta, 2006.

Bengen, D.G. (2000). Sinopsis Ekosistem dan Sumberdaya Alam Pesisir.

Bengen, D.G. (2001). Pedoman Teknis Pengenalan dan Pengelolaan Ekosistem Mangrove. Pusat Kajian Sumber daya Pesisir dan Lautan- Institut Pertanian Bogor. Bogor, Indonesia.

Badan Perencanaan Daerah Provinsi Sumatra Utara (2010). Pengamatan Kondisi Kawasan Hutan Mangrove Sumatra Utara.

Badan Perencanaan Daerah Provinsi Sumatra Utara. (2011). Laporan Tahunan Pembangunan Wialayah.

Creswell, J.W. (1994). Desain Peneitian, Pendekatan Kualitatif \& Kuantitatif. Terjemahan Angkatan III \& IV. Penerbit KIK Press. Jakarta

Dahuri, R. (2002). Integrasi Kebijakan Pengelolaan Sumberdaya Pesisir dan Pulau-Pulau Kecil. Makalah disampaikan pada Lokakarya Nasional Pengelolaan Ekosistem mangrove, 6-7 Agustus 2002. Jakarta.

Dahuri, R. (2003). Keanekaragaman Hayati Laut. Aset Pembangunan Berkelanjutan Indonesia. Penerbit PT Gramedia Pustaka Utama. Jakarta.

Dahuri, R., J. Rais, S.P.Ginting \& M.J. Sitepu. (1996). Pengelolaan Sumberdaya Wilayah Pesisir dan Lautan Secara Terpadu. P.T. Saptodadi. Jakarta.

Data Monografi Desa Takap Kuda. (2012). Pemerintah Desa Tapak Kuda Kecamatan Tanjung Pursa Kabupaten Langkat.

Departemen Kehutanan \& FAO. (1990). Situation and Outlook of the Forestry Sector in Indonesia. Volume 2: Forest Resource Base. UTF/INS/065/INS: Forestry Studies, Technical Report No. 1. Jakarta.

Gunarto. (2004). Konservasi Mangrove Sebagai Pendukung Sumber Hayati Perikanan Pantai. Jurnal Litbang Pertanian, 23(1), 2004.

Gunawan, H. (1995). Keragaman Jenis Ikan, Terumbu Karang dan Flora Fauna Hutan Mangrove, Taman Nasional Laut Bunaken-Manado Tua. LaporanPenelitian. Balai Penelitian Kehutanan. Ujung Pandang. 
Hadipurnomo. (1995). Fungsi dan Manfaat Mangrove di dalam Mintakat Pantai (Coastal Zone). Jurnal Duta Rimba. No XXI, Maret-April 1995. Perum Perhutani. Jakarta.

Irwanmay, (2004). Analisis Konversi Lahan Bakau di Tanjung Pura. Tesis. Universitas Sumatra Utara.

Jakaria. (2000). Analisis Pengelolaan Hutan Mangrove Kearah Wilayah Pantai Berkelanjutan dan Dampaknya Kepada Kesejahteraan Penduduk di Kabupaten Kutai Propinsi Kalimantan Timur. Bogor: Institut Pertanian Bogor.

Kusmana, C., Wilarso, S., Hilwan, I., Pamoengkas, P., Wibowo, C., Tiryana, T., Triswanto, A., Yunasfi, and Hamzah. 2003. Teknik Rehabilitasi Mangrove. Fakultas Kehutanan-Institut Pertanian Bogor.

Sunarto. (2008). Peranan Ekologis dan Antropogenis Ekosistem Mangrove. Karya Ilmiah, Fakultas Perikanan dan Ilmu Kelautan- Universitas Padjadjaran. Bandung.

Sihaloho, Martua. (2004). Konversi Lahan Pertanian dan Perubahan Struktur Agraria. Tesis. Sekolah Pascasarjana. Bogor: Institut Pertanian Bogor

Rochana, E. (2002). Ekosistem Mangrove dan Pengelolaannya di Indonesia. Institute Pertanian Bogor. Bogor. Indonesia.

Nybakken, J. (1992). Biologi Laut Suatu Pendekatan Ekologis. PT Gramedia. Jakarta. 
